\title{
Collaborative Innovation Research on High-tech Industry in the
}

\section{Center Delta}

\author{
Jingdong $\mathrm{Yan}^{1}, \mathrm{Li} \mathrm{Li}^{2, *}$ and Xiangmiao $\mathrm{Liu}^{3}$ \\ ${ }^{1}$ Managment School, Wuhan University of Technology, Wuhan, China \\ ${ }^{2}$ Managment School, Wuhan University of Technology, Wuhan, China \\ ${ }^{3}$ Managment School, Wuhan University of Technology, Wuhan, China \\ Corresponding Email: 1554103284@qq.com
}

\begin{abstract}
As a strong point in the Middle Rises Strategy, the Center Delta is of great significance to high-tech industry development. While the collaborative innovation is an effective way to promote the coordinated development of regional economy. This article selected electronic and communication equipment manufacturing industry of 3 provinces in the Center Delta as samples, built evaluation index system of collaborative innovation of high-tech industry, and put the relevant data into the system coordination degree model, in order to get the synergy of industrial innovation system and innovation environment system of 3 provinces. The empirical results shown that the industrial innovation system and innovation environment system coordination degree of Hubei province was the highest, while Jiangxi province was the lowest. Based on the empirical result analysis of the above-mentioned systems, this article put forward suggestions to promote the development of the high-tech industry collaborative innovation in the Center Delta.
\end{abstract}

Keywords. Collaborative innovation, innovation system, innovation environment.

\section{Instruction}

The Middle Reaches of the Yangtze River, which named "the Center Delta", is the major high-tech industry, advanced manufacturing, modern services and regional scientific and technological innovation bases in China. The Center Delta consist of Hubei wuhan city circle, ring of Changsha-Zhuzhou-Xiangtan urban agglomeration in Hunan province, Jiangxi PoYang lake ecological economic zone.And they are important middle urban agglomerations to carry out the Middle Rises Strategy as well [1]. The Center Delta in the narrow sense refers to the Hubei Wuhan city circle, ring of Changsha-Zhuzhou-Xiangtan urban agglomeration in Hunan province, Jiangxi Poyang Lake ecological economic zone, which contains seven central city(Hubei Wuhan, Changsha, Zhuzhou and Xiangtan in Hunan province, Jiangxi Nanchang, jingdezhen and Yingtan)and urban community formed by 19 cities, municipals or sections. The Center Delta in the broad sense refers to three provinces (Hubei, Hunan and Jiangxi), radiating driven by three major cities (group). Since the development of high-tech industries of the three provinces are mainly concentrated in the three major urban agglomerations (circle), and statistics calibers are given priority to the provinces, we chose to extend the area of research to the whole provinces in where the Center Delta located. 
On September 23th, 2009, the State Council promoted in the Opinions about Vigorously Promoting Central Region Rise Strategy that the state should strengthen modern equipment manufacturing and high-tech industry base, rely on the leading enterprise, master the core technology as the breakthrough point, and give full play to the leading role of Wuhan, Changzhutan regional comprehensive national high-tech industry base and professional radiation national high-tech industry base; in order to form a new industrial clusters with core competitiveness and ultimately would achieve the transformation and upgrading of traditional industries under high-tech conditions [2]. The opinions had strategic importance in putting surrounding provinces on an innovative and developing path which was leading by the Center Delta city group and supported by high-new technology. As an important driving force to promote sustainable development of social economy,high-tech industry with the characteristics of human-financial investment, sophisticated requirements and environment and social sustainable development, undertakes an important role in promoting the regional economy of the Center Delta.

However, as a regional economies, there exists an obvious gap among this region and the Yangtze River Delta and the Pearl Rive Delta, which specific embodiment in serious segmented regional market, isolated development, unclear division of regional industrial labor, low conversion rate of scientific research, unreasonable resources configuration of resources that have great advantages, etc [3].In addition, the gap of high- new technology industry development degree is also obvious among the 3 provinces. All of these factors have weakened the competitiveness of the region, hindering the coordinated development of regional economy in the Center Delta. Thus, it is of great research significance for the Center Delta to find methods of achieving complementary advantages, optimizing the allocation of high-new technology industries resources, promoting the competitiveness and fusion of science\&technology and productivity, forming an overall advantage,taking strong pulling effect on the prosperity of the central region's economy situation, and becoming the engine driving the rise of central China.

\section{Related concepts}

Center Peter A. Gloor, a researcher in MIT Sloan, first gave definition to collaborative innovation: self-motivated staffs with a common vision constituted a group, and aimed to achieve shared goals by exchanging ideas and information through network. Researches based on collaborative innovation began to rise In 1990s [4]. In 1992, the State Economic and Trade Commission, Ministry of Education and Chinese Academy of Sciences jointly organized and implemented the "Joint Development of Research Projects", which had given rise to large quantities of relevant studies. In 2011, collaborative innovation had been put forward. In order to establish an innovative country; universities, research institutes and enterprises were encouraged to expand the depth of cooperation; and innovative elements of vitality (talent, capital, information, technology) should be released.

For the essence of collaborative innovation connotation, domestic scholars had different views. This article tended to adopt Zhitai Zhou's opinion (2013), that the collaborative innovation was an activity about the circulation and integration of inter-organizational and inter-regional human, financial, material and information [5]. It was launched by enterprises, government, universities, research institutes, intermediary service organizations and users and aimed at achieving technological innovation. Collaborative innovation promoted the complementarity of resources and advantages, cooperated to carry out technical innovation and achievement transformation activities through policy guidance and mechanism arrangement, the integration of enterprises, universities and research institutes as well as innovative resources.

\section{Collaborative innovation model}

In this paper, we have studied the triangular cooperative innovation of high-tech industry and have built industry theory model of collaborative innovation. System coordination degree model have been used to evaluate the synergy degree of 
high-tech industry in the Center Delta on the basis of system coordination degree model established by Qingsong Meng, Wenxiu Han (2000) [6].

The order parameter in a economic system development process is ei=(e11, e12, .,e1n), $\mathrm{n} \geq 2, \beta 1 \mathrm{i} \leq \mathrm{e} 1 \mathrm{i} \leq \alpha 1 \mathrm{i}, \mathrm{i} \in[1, \mathrm{n}]$. $\mathrm{e} 11, \mathrm{e} 12, \ldots, \mathrm{e} 1 \mathrm{n}$ are the indexes to describe the economic system operation mechanism and operation condition. When the indexes are positive,the bigger e11, e12, ., eln are,the higher the order degree is,otherwise the opposite.When the indexes are negative, the bigger e11, e12, ., eln are,the lower the order degree is,otherwise the opposite.Therefore, the following equation is defined as a system component of the order parameter of the degree of order:

$$
u_{1}\left(e_{1 i}\right)=\left\{\begin{array}{l}
\frac{e_{1 i}-\beta_{1 i}}{a_{1 i}-\beta_{1 i}}, e_{1 i} \text { are positive indexes } \\
\frac{a_{1 i}-e_{1 i}}{a_{1 i}-\beta_{1 i}}, e_{1 i} \text { are positive indexes }
\end{array}\right.
$$

$u_{1}\left(e_{1 i}\right) \in[0,1]$, the smaller $u_{1}\left(e_{1 i}\right)$ is, the smaller contribution has been made to the industry innovation subsystem degree of order.

Subsystem degree of order can be measured by index degree of order. The contribution order parameter $e_{1}$ made to industry innovation system can be achieved through the integration of ${ }^{u_{1}\left(e_{l i}\right)}$. Geometric method and weighted sum method are commonly used in practice, that is:

$$
\begin{gathered}
u_{1}\left(e_{l i}\right)=\sqrt[n]{\prod_{j=1}^{n} u_{1}\left(e_{i j}\right)} \\
\text { or: } u_{1}\left(e_{l i}\right)=\sum_{j=1}^{n} \omega_{j} u_{1}\left(e_{l i}\right), \omega_{j} \geq 0, \sum_{j=1}^{n} \omega=1
\end{gathered}
$$

This paper adopted weighted sum method, and environment subsystem degree of order can be calculated as $u_{2}\left(e_{2 i}\right)$.

The synergy degree of high-tech industries collaborative innovation system can be identified according to the order degree of innovation subsystem. Collaborative innovation of the system refers to the degree of coordination of the various subsystems in the innovation process, and was decided by degree of order collective of each subsystem. The improvement of individual system degree of order can not lead to the improvement of coordination degree of the whole system. The improvement of system coordination degree is decided by ordered degree of the whole system.

System order degree of innovation System order parameter is $u_{1}^{0}\left(e_{1}\right)$ at the given initial point.So for t1 in the development of system evolution, if the System order degree of innovation System order parameter is $u_{1}^{1}\left(e_{1}\right)$, the order degree of innovation environment system is $u_{2}^{1}\left(e_{2}\right)$, and $u_{1}^{1}\left(e_{1}\right) \geq u_{1}^{0}\left(e_{1}\right), u_{2}^{1}\left(e_{2}\right) \geq u_{2}^{0}\left(e_{2}\right)$ are both satisfied, it can be said that high-tech industry collaborative innovation system is developing collaboratively in the period from to to t 1 . The following is a model for computing system coordination degree:

$$
c=\lambda \sqrt{\nwarrow u_{1}^{1}\left(e_{1}\right)-u_{1}^{0}\left(e_{1}\right) \nwarrow \cdot \pi u_{2}^{1}\left(e_{2}\right)-u_{2}^{0}\left(e_{2}\right)}
$$




$$
\lambda=\left\{\begin{aligned}
1, & u_{1}^{1}\left(e_{1}\right)-u_{1}^{0}\left(e_{1}\right) \geq 0 \\
-1, & \text { other }
\end{aligned}\right.
$$

As is shown in the system coordination degree model: ${ }^{c \in[-1,1]}$, the smaller $c$ is, the lower the degree of coordinated development system is, otherwise the opposite.

If one of the subsystems' the increasing amount of order degree is larger, while the other subsystem has smaller increasing amount, then the synergy degree of the whole system is at a lower level, which means the system is not in a state of good coordination or not harmonious.

\section{Empirical analysis}

\subsection{Collaborative innovation evaluation index system}

In this paper, we have studied the collaborative innovation between industrial innovation system and innovation environment system, then have established an index system based on the characteristics of elements and systems.

Industrial innovation system indicated innovation capacity and performance of the industry. Ten indexes were chosen in this study, including S\&T Personnel, Scientists and Engineers, Full-time Equivalent of R\&D Personnel, New Fixed Assets, Funding for S\&T Activities, Intramural Expenditure on R\&D, Patent Applications, Output Value of New Products, Export Sales Revenue of New Products, GDP at Current Prices [7].

(1)S\&T Personnel refers to person who are engaged in the activities of science and technology directly or indirectly , as well as people providing service for science and technology activities. This index reflects human input of industry innovation system.(2)The Number of Scientists and Engineers refers to the number of people with medium and senior technical titles and those who have received college or higher education but don't have medium or senior technical titles. This index reflects the R\&D investment of the industry innovation system and creativity of science and technology. (3) Full-time Equivalent of R\&D Personnel refers to the number of person-years of full-time personnel accounting of R\&D project research personnel, management personnel and direct service personnel. The index reflects the actual workload of R\&D investment of industrial innovation system. (4)New Fixed Asset refers to the increasing value of fixed assets in the reporting year. The index reflects cumulative capacity of industrial innovation system infrastructure.(5)Funding for S\&T Activities reflects the science and technology investment situation of industry innovation system.(6)Intramural Expenditure on R\&D refers to internal spending for research activities. This index reflects the investment of research and development funds of industrial innovation system.(7)Patent Applications refers to the number of patents that a particular industry applied, reflects the industrial R\&D ability.(8)Output Value of New Products refers to new products adopted new technology, new design; or new products which performance and functions are significantly improved, a significant increase in product output and use function, reflects the innovation output of the system.(9)Export Sales Revenue of New Products refers to the new products export value proportion of the total export value. The index reflects the new products' market competitiveness of industrial innovation system [8].(10)GDP at Current Prices refers to industrial production output value of the current period. The index reflects the production capacity of industrial innovation system.

Innovative Environment System indicates the industry's innovation environment. Three indexes were chosen in the study, including the Number of Research Institutions, Microelectronic Control Equipment and the Government Funds in the investment.

(1)The Number of Research Institutions refers to the institutions engaged in scientific research and technological development activities, and had science and technology activities expenditure. The index reflects creating, accessing and the spreading situation of knowledge and technology of the innovative environmental system.

(2)Original value of Equipment Controlled by Micro-electronics represents the industry informatization level, informatization of production equipment is conducive to improve production efficiency and reduce production costs. 
(3)Government Funds in the Investment reflects the government's efforts to support the industrial development.

\section{2 Data sources and analysis}

This article collected 5 years' $(2005,2008,2009,2010,2011)$ electronic and communication equipment manufacturing industry data from"China Statistical Yearbook on High Technology Industry" as shown in the table 1 and table 2. The difference between the evaluation of observation units in the subsystems resulted in significant differences between the observed values. So the raw data should be standardized before empirical analysis.

After standardizing the data, we put them into formula(1), computed degree of order of industry innovation system and innovation environment syste, at the same time, analyzed the correlation of each index system, the results are shown in table 3 and table 4.

CRITIC objective weighting method was used to calculate the weight of each component of the industry innovation system and the innovation environment in the Center Delta as shown in table 5 and table 6.

Put the degree of order and weighted value of the components in the industry innovation system into formula(3), degree of order of industry innovation system could be concluded, degree of order of innovation environment system could be calculated in the same way. Then put the degree of order data of the two systems into formula(4), the coordination degree of system could be obtained. The results are shown in table 7 .

Table 1. The raw data of Industry Innovation System Index in the Center Delta.

\begin{tabular}{|c|c|c|c|c|c|c|c|c|c|c|c|}
\hline $\begin{array}{l}\text { Reg } \\
\text { ion }\end{array}$ & Year & $\begin{array}{l}\text { S\&T } \\
\text { Pers } \\
\text { onne } \\
1 \\
\text { (pers } \\
\text { on) }\end{array}$ & $\begin{array}{c}\text { New } \\
\text { Fixed } \\
\text { Asset } \\
\text { (100mil } \\
\text { lionyua } \\
\text { n) }\end{array}$ & $\begin{array}{c}\text { Fundin } \\
\text { g for } \\
\text { S\&T } \\
\text { Activiti } \\
\text { es } \\
(10000 \\
\text { yuan) }\end{array}$ & $\begin{array}{l}\text { Scient } \\
\text { ists } \\
\text { And } \\
\text { Engin } \\
\text { eers } \\
\text { (perso } \\
\text { n) }\end{array}$ & $\begin{array}{c}\text { Full-tim } \\
\text { e } \\
\text { Equivale } \\
\text { nt Of } \\
\text { R\&D } \\
\text { Personne } \\
1 \\
\text { ( man-ye } \\
\text { ar) }\end{array}$ & $\begin{array}{c}\text { Intramu } \\
\text { ral } \\
\text { Expend } \\
\text { iture } \\
\text { on } \\
\text { R\&D } \\
\text { (10000 } \\
\text { yuan) }\end{array}$ & $\begin{array}{l}\text { Patent } \\
\text { Applicat } \\
\text { ions } \\
\text { (person) }\end{array}$ & $\begin{array}{l}\text { Output } \\
\text { Value of } \\
\text { New } \\
\text { Products } \\
\text { (10000 } \\
\text { yuan) }\end{array}$ & $\begin{array}{l}\text { export } \\
\text { sales } \\
\text { revenue } \\
\text { of new } \\
\text { products } \\
\text { (10000 } \\
\text { yuan) }\end{array}$ & $\begin{array}{c}\text { GDP at } \\
\text { current } \\
\text { price } \\
(100 \\
\text { million } \\
\text { yuan) }\end{array}$ \\
\hline \multirow{5}{*}{$\underset{\text { ei }}{\mathrm{Hub}}$} & $\begin{array}{c}200 \\
7\end{array}$ & $\begin{array}{c}12,1 \\
39\end{array}$ & 35.61 & 6652 & 2568 & 8765 & 62963 & 12 & 1258699 & 553879 & 447.5 \\
\hline & $\begin{array}{c}200 \\
9\end{array}$ & $\begin{array}{c}17,5 \\
58\end{array}$ & 59.36 & 8569 & 2986 & 8965 & 103056 & 89 & 1889872 & 586972 & 847.5 \\
\hline & $\begin{array}{c}201 \\
1\end{array}$ & $\begin{array}{c}19,5 \\
74\end{array}$ & 113.49 & 9158 & 3522 & 7790 & 183112 & 120 & 3584687 & 669875 & 1039.5 \\
\hline & $\begin{array}{c}201 \\
3\end{array}$ & $\begin{array}{c}21,4 \\
97\end{array}$ & 160.93 & 16998 & 4622 & 9532 & 166053 & 269 & 3886245 & 887754 & 1312.0 \\
\hline & $\begin{array}{c}201 \\
5\end{array}$ & $\begin{array}{c}22,1 \\
42\end{array}$ & 229.47 & 17223 & 5890 & 13258 & 372111 & 390 & 4002587 & $\begin{array}{c}1025879 \\
6\end{array}$ & 1721.0 \\
\hline \multirow{5}{*}{$\begin{array}{c}\text { Hun } \\
\text { an }\end{array}$} & $\begin{array}{c}200 \\
7\end{array}$ & $\begin{array}{c}6,90 \\
8\end{array}$ & 30.39 & 3560 & 1768 & 3458 & 18603 & 1 & 985443 & 200154 & 219.3 \\
\hline & $\begin{array}{c}200 \\
9\end{array}$ & $\begin{array}{c}11,4 \\
90\end{array}$ & 50.46 & 4225 & 2213 & 3698 & 46367 & 3 & 1344126 & 324877 & 522.8 \\
\hline & $\begin{array}{c}201 \\
1\end{array}$ & $\begin{array}{c}12,9 \\
10\end{array}$ & 81.60 & 4889 & 2610 & 1998 & 76954 & 25 & 1523954 & 387514 & 648.8 \\
\hline & $\begin{array}{c}201 \\
3\end{array}$ & $\begin{array}{c}15,7 \\
76\end{array}$ & 124.40 & 5336 & 3325 & 2598 & 84600 & 66 & 2103987 & 455536 & 930.6 \\
\hline & $\begin{array}{c}201 \\
5\end{array}$ & $\begin{array}{c}21,4 \\
07\end{array}$ & 153.06 & 7325 & 4476 & 3120 & 128016 & 127 & 3158976 & 514783 & 1544.9 \\
\hline \multirow{5}{*}{$\begin{array}{r}\text { Jian } \\
\text { gxi }\end{array}$} & $\begin{array}{c}200 \\
7\end{array}$ & $\begin{array}{c}10,9 \\
87\end{array}$ & 46.54 & 3882 & 650 & 5769 & 42928 & 2 & 688521 & 784423 & 234.0 \\
\hline & $\begin{array}{c}200 \\
9\end{array}$ & $\begin{array}{c}17,2 \\
67\end{array}$ & 160.18 & 4153 & 710 & 6582 & 52963 & 29 & 1325897 & 254648 & 586.0 \\
\hline & $\begin{array}{c}201 \\
1\end{array}$ & $\begin{array}{c}18,5 \\
71\end{array}$ & 215.18 & 4523 & 779 & 6132 & 77507 & 37 & 1569872 & 354742 & 755.7 \\
\hline & $\begin{array}{c}201 \\
3\end{array}$ & $\begin{array}{c}21,8 \\
10\end{array}$ & 356.27 & 7960 & 890 & 5887 & 101994 & 96 & 2225987 & 365872 & 1037.5 \\
\hline & $\begin{array}{c}201 \\
5\end{array}$ & $\begin{array}{c}23,9 \\
99\end{array}$ & 329.79 & 8763 & 936 & 6117 & 133261 & 189 & 3004894 & 420457 & 1418.6 \\
\hline
\end{tabular}

Table 2. The raw data of Environmental Innovation System Index in the Center Delta. 


\begin{tabular}{ccccc}
\hline \multirow{6}{*}{ Hubei } & $\begin{array}{c}\text { Institutions } \\
\text { (unit) }\end{array}$ & $\begin{array}{c}\text { Controlled by Micro-electronics } \\
(10000 \text { yuan })\end{array}$ & $(10000$ yuan $)$ \\
& 2007 & 25 & 100,234 & 1,586 \\
& 2009 & 31 & 112,350 & 3,562 \\
& 2011 & 38 & 128,756 & 5,523 \\
& 2015 & 42 & 135,692 & 8,895 \\
\multirow{6}{*}{ Hunan } & 2007 & 50 & 142,388 & 10,256 \\
& 2009 & 7 & 3,215 & 982 \\
& 2011 & 11 & 3,865 & 1,235 \\
& 2013 & 16 & 4,230 & 1,890 \\
\multirow{6}{*}{ Jiangxi } & 19 & 5,663 & 2,360 \\
& 2015 & 21 & 6,349 & 3,356 \\
& 2007 & 6 & 1,963 & 1,095 \\
& 2011 & 8 & 2,536 & 2,089 \\
& 2013 & 13 & 3,025 & 2,698 \\
& 2015 & 14 & 3,560 & 3,469 \\
\hline
\end{tabular}

Table 3. Index correlation coefficient of Industry innovation system in the Center Delta.

\begin{tabular}{|c|c|c|c|c|c|c|c|c|}
\hline \multicolumn{9}{|c|}{ Hubei Province } \\
\hline 1.000 & 0.023 & 0.919 & 0.995 & 0.712 & 0.824 & 0.895 & 0.919 & 0.925 \\
\hline 0.023 & 1.000 & 0.072 & 0.034 & 0.596 & 0.205 & 0.071 & 0.354 & 0.365 \\
\hline 0.919 & 0.072 & 1.000 & 0.889 & 0.607 & 0.849 & 0.977 & 0.783 & 0.812 \\
\hline 0.995 & 0.034 & 0.889 & 1.000 & 0.729 & 0.774 & 0.880 & 0.936 & 0.940 \\
\hline 0.712 & 0.596 & 0.607 & 0.729 & 1.000 & 0.298 & 0.662 & 0.482 & 0.483 \\
\hline 0.824 & 0.205 & 0.849 & 0.774 & 0.298 & 1.000 & 0.725 & 0.744 & 0.754 \\
\hline 0.895 & 0.071 & 0.977 & 0.880 & 0.662 & 0.725 & 1.000 & 0.775 & 0.808 \\
\hline 0.919 & 0.354 & 0.783 & 0.936 & 0.482 & 0.744 & 0.775 & 1.000 & 0.998 \\
\hline 0.925 & 0.365 & 0.812 & 0.940 & 0.483 & 0.754 & 0.808 & 0.998 & 1.000 \\
\hline 0.887 & 0.094 & 0.775 & 0.858 & 0.558 & 0.907 & 0.661 & 0.766 & 0.757 \\
\hline \multicolumn{9}{|c|}{ Hunan Province } \\
\hline 1.000 & 0.646 & 0.904 & 0.955 & 0.798 & 0.638 & 0.942 & 0.379 & 0.181 \\
\hline 0.646 & 1.000 & 0.528 & 0.660 & 0.066 & 0.426 & 0.686 & 0.195 & 0.187 \\
\hline 0.904 & 0.528 & 1.000 & 0.918 & 0.771 & 0.250 & 0.978 & 0.130 & 0.034 \\
\hline 0.955 & 0.660 & 0.918 & 1.000 & 0.763 & 0.506 & 0.941 & 0.345 & 0.113 \\
\hline 0.798 & 0.066 & 0.771 & 0.763 & 1.000 & 0.487 & 0.692 & 0.683 & 0.266 \\
\hline 0.638 & 0.426 & 0.250 & 0.506 & 0.487 & 1.000 & 0.359 & 0.705 & 0.380 \\
\hline 0.942 & 0.686 & 0.978 & 0.941 & 0.692 & 0.359 & 1.000 & 0.093 & 0.041 \\
\hline 0.379 & 0.195 & 0.130 & 0.345 & 0.683 & 0.705 & 0.093 & 1.000 & 0.198 \\
\hline 0.181 & 0.187 & 0.034 & 0.113 & 0.266 & 0.380 & 0.041 & 0.198 & 1.000 \\
\hline 0.393 & 0.784 & 0.526 & 0.566 & 0.047 & 0.132 & 0.596 & 0.448 & 0.646 \\
\hline \multicolumn{9}{|c|}{ Jiangxi Province } \\
\hline 1.000 & 0.962 & 0.941 & 0.988 & 0.059 & 0.950 & 0.909 & 0.825 & 0.968 \\
\hline 0.962 & 1.000 & 0.956 & 0.939 & 0.049 & 0.962 & 0.838 & 0.729 & 0.987 \\
\hline 0.941 & 0.956 & 1.000 & 0.942 & 0.327 & 0.925 & 0.894 & 0.860 & 0.987 \\
\hline 0.988 & 0.939 & 0.942 & 1.000 & 0.156 & 0.963 & 0.962 & 0.890 & 0.963 \\
\hline 0.059 & 0.049 & 0.327 & 0.156 & 1.000 & 0.103 & 0.342 & 0.543 & 0.195 \\
\hline 0.950 & 0.962 & 0.925 & 0.963 & 0.103 & 1.000 & 0.924 & 0.805 & 0.967 \\
\hline 0.909 & 0.838 & 0.894 & 0.962 & 0.342 & 0.924 & 1.000 & 0.963 & 0.899 \\
\hline 0.825 & 0.729 & 0.860 & 0.890 & 0.543 & 0.805 & 0.963 & 1.000 & 0.823 \\
\hline 0.968 & 0.987 & 0.987 & 0.963 & 0.195 & 0.967 & 0.899 & 0.823 & 1.000 \\
\hline 0.986 & 0.948 & 0.956 & 0.999 & 0.184 & 0.970 & 0.962 & 0.892 & 0.974 \\
\hline
\end{tabular}

Table 4. Index correlation coefficient of Environmental Innovation System in the Center Delta.

\begin{tabular}{ccccccccc}
\hline & \multicolumn{3}{c}{ Hubei Province } & \multicolumn{3}{c}{ Hunan Province } & \multicolumn{3}{c}{ Jiangxi Province } \\
\hline 1.000 & 0.785 & 0.603 & 1.000 & 0.272 & 0.711 & 1.000 & 0.978 & 0.325 \\
0.785 & 1.000 & 0.582 & 0.272 & 1.000 & 0.271 & 0.978 & 1.000 & 0.319 \\
\hline
\end{tabular}




\begin{tabular}{cccccccccccc}
\hline 0.603 & 0.582 & 1.000 & 0.711 & 0.271 & 1.000 & 0.325 & 0.319 & 1.000 \\
\hline \multicolumn{7}{c}{ Table 5. The weight of each component } \\
\hline \multicolumn{7}{c}{ of Industry innovation system in the Center Delta. } \\
\hline Region & W1 & W2 & W3 & W4 & W5 & W6 & W7 & W8 & W9 & W10 \\
\hline $\begin{array}{c}\text { Hubei } \\
\text { Provinc }\end{array}$ & 0.0567 & 0.2747 & 0.0717 & 0.0592 & 0.1124 & 0.0969 & 0.0782 & 0.0841 & 0.0859 & 0.0797 \\
$\begin{array}{c}\text { Hunan } \\
\text { Provinc } \\
\text { Jiangxi }\end{array}$ & 0.0647 & 0.0856 & 0.0696 & 0.0684 & 0.0974 & 0.1119 & 0.6358 & 0.1768 & 0.1587 & 0.1285 \\
Provinc & 0.0564 & 0.0638 & 0.0688 & 0.0557 & 0.4041 & 0.0625 & 0.0758 & 0.1007 & 0.0628 & 0.0552 \\
\hline
\end{tabular}

Table 6. The weight of each component of Innovation Environmental System in the Center Delta.

\begin{tabular}{ccccccccc}
\hline & Hubei Province & \multicolumn{3}{c}{ Hunan Province } & \multicolumn{3}{c}{ Jiangxi Province } \\
\hline W1 & W2 & W3 & W1 & W2 & W3 & W1 & W2 & W3 \\
0.2854 & 0.3057 & 0.4201 & 0.3408 & 0.4369 & 0.2235 & 0.2528 & 0.2551 & 0.4921 \\
\hline
\end{tabular}

Table 7. Degree of coordination of High-tech industry collaborative innovation in the Center Delta.

\begin{tabular}{|c|c|c|c|c|c|c|c|c|c|}
\hline \multirow[b]{2}{*}{ Year } & \multicolumn{3}{|c|}{ Hubei Province } & \multicolumn{3}{|c|}{ Hunan Province } & \multicolumn{3}{|c|}{ Jiangxi Province } \\
\hline & $\begin{array}{c}\text { Industrial } \\
\text { innovation } \\
\text { system } \\
\text { degree of } \\
\text { order } \\
\end{array}$ & $\begin{array}{c}\text { Innovation } \\
\text { environme } \\
\text { nt system } \\
\text { degree of } \\
\text { order }\end{array}$ & $\begin{array}{l}\text { Degree of } \\
\text { coordinati } \\
\text { on }\end{array}$ & $\begin{array}{c}\text { Industrial } \\
\text { innovation } \\
\text { system } \\
\text { degree of } \\
\text { order } \\
\end{array}$ & $\begin{array}{c}\text { Innovation } \\
\text { environmen } \\
\text { t system } \\
\text { degree of } \\
\text { order } \\
\end{array}$ & $\begin{array}{l}\text { Degree of } \\
\text { coordinati } \\
\quad \text { on }\end{array}$ & $\begin{array}{c}\text { Industrial } \\
\text { innovation } \\
\text { system } \\
\text { degree of } \\
\text { order } \\
\end{array}$ & $\begin{array}{c}\text { Innovatio } \\
n \\
\text { environm } \\
\text { ent } \\
\text { system } \\
\end{array}$ & $\begin{array}{c}\text { Degree } \\
\text { of } \\
\text { coordinati } \\
\text { on }\end{array}$ \\
\hline $\begin{array}{c}200 \\
7\end{array}$ & 0.0202 & 0.0245 & & 0.3520 & 0.5175 & & 0.0775 & 0.5125 & \\
\hline $\begin{array}{c}200 \\
9\end{array}$ & 0.4911 & 0.3031 & 0.3623 & 0.2070 & 0.3946 & 0.1335 & 0.0433 & 0.0000 & -0.1324 \\
\hline $\begin{array}{c}201 \\
1\end{array}$ & 0.3393 & 0.2579 & 0.2729 & 0.5689 & 0.2367 & -0.2468 & 0.4919 & 0.1645 & -0.3798 \\
\hline $\begin{array}{c}201 \\
3\end{array}$ & 0.7150 & 0.4676 & 0.5549 & 0.6523 & 0.4651 & 0.3148 & 0.4452 & 0.1793 & -0.3500 \\
\hline$\frac{201}{5}$ & 0.7433 & 0.6480 & 0.8399 & 0.6586 & 0.6698 & 0.3286 & 0.6011 & 0.4506 & 0.4208 \\
\hline
\end{tabular}

\subsection{Result analysis}

From2009, the ordered degree of Industry innovation system calculation in 3 provinces has been always increasing. Hubei province reached the highest ordered degree of Industry innovation system in 2015, the Funding for S\&T Activities and the Patent Applications number were significantly higher than the other years according to the raw data. Since 2009, ordered degree of industry innovation system of Jiangxi province has improved obviously [9]. S\&T Activities number, New Fixed Assets and Scientists and Engineers number have been increasing. It could be seen that the input of innovation system has put great impact on the ordered degree of industry innovation system.

The calculation of the ordered degree of Innovation environment system shown the following information: In addition to 2011, ordered degree of innovation environment has been gradually improving. The Degree of order of Innovation environment system from 2009 to 2013 in Hunan province has been obviously increasing, while for the past two years, the government funds was much higher than the other years. As for Jiangxi province, the government funds in 2011 was much higher. It could be seen that government plays an important role in the innovation environmental system.

The Synergy degree calculation results of Industry innovation system and Innovation environment system indicated that from 2007 to 2015, Collaborative degree has increased compared to last year. All regions have attached great importance to developing Industry innovation as well as improving Innovation environment, which has contributed to the coordinated development of industry innovation system and innovation environment system. 
The synergy of industry innovation system and innovation environment system has positive effects on the rapid and benign development of high-tech industries. By means of collaborative innovation, product performance has been improved constantly, the yield of new product has increased, and industry innovation and innovation environment have promoted mutually, which enhance the competitiveness of high-tech industries [10].

\subsection{Cultivation and introduction of talents}

Through the empirical study of coordination degree of the industry innovation system and innovation environment system, the number of scientists and engineers in the industry innovation system has been found having important effects on the synergy degree. Therefore, talent factor, not only the cultivation of the talent but also the flow of talent, should be paid great attention to. In recent years, Hubei province and Hunan province have cultivated and attracted a large number of talents through their respective strengths. Relatively speaking, Jiangxi province is weaker on education and scientific research, and lacks in cultivating talents as well. What's more, Jiangxi province started later in introducing talents. From an overall perspective, market orientation should be adopted, in order to speed up the talent flow and promote the communications among scientific research personnel through the guidance of profit-driven or policies.

\subsection{Increase the science and technology funds}

The mount of funds raised for science and technology activities andgovernment funds have a great impact on the system synergy. Thus the government should pay more attention to play a important role in industrial innovation system and innovation environment system in the development of collaborative innovation. Economic methodsshould be taken to provide direct financial support and indirect incentive and supporting policies for the development of high-tech industry. Such as tax relief, establishing a financial system that contains a diversified venture capital system, etc. These related policies not only guide enterprises to increase R \& D investment, but also broaden the financing channels of high-tech enterprises so that it can provide powerful fund guarantee for new high-tech enterprises and drive them to develop collectively and form a large scale.

\subsection{Encourage technological innovation}

The number of patent applications has a certain influence on the order degree of industrial innovation system and the synergy degree of the whole system [11]. Therefore, the government should formulate and implement the corresponding policies which are conducive to the collaborative innovation development of high-tech industry, create a good atmosphere of innovation environment, for example, establishing and perfecting the legal protection system, improving the patent protection system, in order to safeguard the legitimate rights and interests of enterprises and scientific research personnel earnestly and then advance the begin development of high and new technology industry.

\section{References}

1. S.L. Zhang, D. Hu, J.C. Liu. The analysis of industrial synergy innovation in Hi-tech industry among Jing-Jin-Ji region. Journal of Hebei University of Technology, (2012)

2. Y.Q. Xu, X.Q. Xin. Research on high-tech industry cluster innovation ability evaluation index system—-based on Collaborative Innovation Theory.Industrial \& Science Tribune, 18:48-50,(2014) 
3. China vertical and horizontal planning research group in 12th Five-Year,"12th Five-Year" planning outline, $3: 32-33,(2010)$

4. Opinions of the State Council on Implementing the Strategy of the Rise of Central China,(2012)

5. B.L. Liu, Y.C. Ma. Study on Coordinative Development between Hi-tech Industry Cluster and Innovation-oriented City .Science \& Technology Progress and Policy, 15:71-73,(2010)

6. S.H. Hu, R.Y. Mu. Situation analysis and strategic countermeasures of Wuhan east lake national innovation demonstration zone.Wuhan press, 1: 54-55,(2011)

7. J.Y. Zhang. High-tech industry cluster innovation collaborative mechanism. Contemporary Economics, 10:140-141, (2011)

8. J. Yu. Collaborative innovation model research on high-tech industry cluster. Research on Financial and Economic Issues, 12:41-44, (2008)

9. M. Shapiro. Innovation: A Blueprint for Surviving and Thriving in an Age of Change. McGraw-Hill, 102-111,(2002)

10. J.Y. Zhang. Collaborative Innovation research of high-tech industry cluster in Wuxi. Science \& Technology Information, 05:273,(2013)

11. B. Tucker. Driving Growth through Innovation. Berrett-Koehler Publishers, Inc. San Francisco, (2002) 